\title{
Parish banking in informal credit markets: the business of private lending in early nineteenth-century Sweden
}

\author{
HÅKAN LINDGREN \\ Stockholm School of Economics
}

\begin{abstract}
This study demonstrates the existence of a private, informal and lively credit market in rural Sweden during the I 840 S, a period that predates the development of a modern banking system. The market, mainly based on private promissory notes, was concentrated in the hands of a limited number of wealthy farmers who specialized in lending, They facilitated access to credit to well-off farmers, regardless of whether they owned their farms or leased taxed land. By using information from probate inventories, the article analyses the wealth portfolio and characteristics of the lending business of the largest creditors ('parish bankers') in a judicial district of southern Sweden in $\mathrm{I} 84 \mathrm{I}-5$. The heart and soul of their business was an intimate knowledge of borrowers' creditworthiness and mutual trust, as typical of local credit networks. The article also explores the existence of an intergenerational transmission of parish banking business - a dimension of private lending that opens an original path of research on local credit markets in early modern Europe.
\end{abstract}

Keywords: informal credit markets, promissory notes, parish bankers, intergenerational banking

JEL classification: $\mathrm{G}_{23}, \mathrm{~N}_{23}, \mathrm{~N} 83$

This micro study of private lending in pre-industrial Sweden is an offshoot of a wider research project on informal credit markets prior to the institutionalization of banking intermediation. In Sweden, banks developed slowly during the nineteenth century, as savings and commercial banks began to emerge in the I 820 s and I830s, followed by

H. Lindgren, Professor Emeritus, Institute for Economic, Business and Financial History Research EHFF (www.ehff.se), Stockholm School of Economics, Box 650I, S-II3 83 Stockholm, Sweden; email: hakan.lindgren@hhs.se. The research program 'Informal Financial Markets in the Nineteenth Century Sweden' involves five post-doc researchers and one $\mathrm{PhD}$ student at the Institute for Economic and Business History Research (EHFF), Stockholm School of Economics, and is financed mainly by the Swedish Foundation for Humanities and Social Science, the Wallenberg Economic History Foundation, Handelsbankens forskningsstiftelser, the Jacob Wallenberg Foundation and the Gunvor and Josef Anér Foundation. A preliminary version of this article was presented at the Twentieth Congress of the European Business History Association (20I6) in Bergen, Norway. I thank the participants, as well as two anonymous referees for helpful comments. 
regional mortgage associations since the I840s. At the national level, institutionalized banking did not take off until the last quarter of the century. By I900, however, the role of informal credit markets was still relevant. Local studies suggest that in the early I90os the market for private promissory notes still accounted for at least one-third of total credit in urban areas, whereas in rural areas the figure could be as high as twothirds (Hellgren 2003, pp. 56-7I; Lilja 2004, pp. I29-48; Lindgren 2002; Perlinge 2005, pp. I09-I2, 264-5).

In this study I follow a business history approach to analyse the business of individual 'parish bankers' - the largest suppliers of loans, identified on the basis of the weight of financial assets in their wealth portfolios - in Norra Möre, a rural judicial district in south-eastern Sweden, in the early I 840s. Section I provides a review of existing research on informal credit markets with a special focus on 'parish banking' in a Swedish context. Section II motivates the choice of the judicial district of Norra Möre as the field of investigation. Section III describes the data set based on estate probate inventories and discusses issues related to the correct valuation of financial items (claims and liabilities), compared to real estate and moveable property, that arise from Swedish probate records. Sections IV and V analyse the characteristics of the lending business of the largest individual creditors and compare the weight of their financial assets to their investments in real estate, other capital assets and household goods. Section vi expands the analysis further by studying the geographical and social structure of outstanding claims. Finally, Section VII explores the intergenerational transmission of 'parish banking' business within the families studied, to explore the possible existence of rural 'financial dynasties'. Section VIII concludes and discusses implications for future research.

\section{I}

The existence of local private markets for credit in early modern Europe and North America is an established fact that traditionally attracted the interest of researchers in economic history and anthropology (Holderness I976; Muldrew I998, pp. 95-I I9; Hoffman et al. 2000, pp. 273-300; Gelderblom et al. 2016; Dermineur 2015, among others). In his impressively rich study on the credit and social relations in early modern England, Craig Muldrew contends that 'debt and credit are probably almost universal in most societies, and have certainly been common to Europe throughout its history'. He also observes that the development of credit markets in pre-industrial economies in Western Europe can be explained to a large extent by a chronic shortage of money as a medium of exchange in coincidence with the expansion of markets and the multiplication of transactions (Muldrew I998, pp. 95, I00-3). A recent case study dealing with a Scandinavian economy is that of Carsten Rasmussen, who uncovered the existence of a thick local loan market in Denmark in the seventeenth century. Using court records in the Gram district in North Schleswig, Rasmussen investigated how a previously flourishing credit economy collapsed during the wars of I657-60. Although he did not use explicitly the term 'parish bankers', he focused on a group 
of large local lenders before the wars and examined the size, term and geographic distribution of their loans (Rasmussen 2010, pp. 77-I I6). ${ }^{1}$

Unlike neighbouring Denmark, the practice of registering loans with a notary (which was also typical of France: Hoffman et al. 2000) never became established in Sweden. The absence of notarial records is partly offset by the existence of records for loans litigated in courts. Yet in the first half of the nineteenth century, private loans mortgaged and registered in the local court were still quite an exception in the Swedish countryside, as the vast majority of them were secured by personal guarantees. As a consequence, in order to study informal credit markets in Sweden before the rise of institutionalized banking, researchers must rely on the records of financial claims and liabilities found in inventories and probate records.

The existing literature on private loan markets in Sweden suggests that a strong concentration on the supply side was typical in local agrarian economies. Maths Isacson's early, and in many ways path-breaking, research on social differentiation at the local level noted that in the parish studied there existed a small number of individuals who provided such a substantial volume of credit that they could be easily labelled 'village financiers'. They contributed to the financing of the developing proto-industry within their judicial district. In certain families lending activities were transmitted across generations and eventually led to the establishment of both merchant manufacturing firms and, later on, factories in the expanding textile industry (Ahlberger I988, pp. 20-30; Isacson I979, p. I45). Patrick Svensson's study focused on borrowing by agricultural entrepreneurs that were active in the agricultural modernization of three Scania parishes during the nineteenth century. He found that, among the credit suppliers (both through notes secured by registration at the local courts and other kinds of loans), some farmers were so dominant that they deserved to be called 'peasant bankers' (Svensson 200 I, pp. I60-4, I90-5). In a later contribution, Svensson used estate inventories from two smaller parishes located in the Scania flatlands to explore the existence of a functioning credit market in the late eighteenth century. Here he used the expression 'peasant bankers' for local creditors with financial claims equal to more than 90 per cent of their estate's assets (the latter were not corrected for possible under-valuations) - an outstanding stock large enough to suggest that 'it is probable that this money lending business was very important for them' (Svensson 2004, pp. 4, 9-10). By applying a social network approach to the study of a parish in central Sweden, Karin Nibon reached similar conclusions, as the interconnection of households on the base of debt relationships uncovered a strong concentration of lending business in the hands of few individuals (Nibon 20I6, pp. 92-7).

The concept of 'parish banker' was introduced and operationalized in the Swedish historiography by Anders Perlinge in his cultural and economic historical study of Vånga parish. Here he clearly defined a set of criteria that could be applied to

${ }^{1}$ In his sample, the largest lender had 48 loans outstanding, distributed among 23 different debtors largely concentrated in the local area. 
estate records in order to identify a 'parish banker' as a supplier of a volume of credit of a sufficient size and breadth, principally on a local scale (Perlinge 2005 , pp. I23-4). ${ }^{2}$ On the basis of such criteria, he found a total of 24 'parish bankers' over a period of 60 years. In 75 per cent of these cases, outstanding notes exceeded the value of the rest of the estate's assets (real estate, capital goods such as equipment and livestock, and household goods). Moreover, virtually all of them had a net positive financial portfolio with claims exceeding debts. Family borrowing was relatively small, as it was found only in ten cases and accounted for only 27 out of 400 loan transactions. The concentration of credit on the lender's own parish, as well as the extensive presence of probate referees and bank officials (following the establishment of the local savings bank in I870) in the pool of borrowers, confirmed the importance of trust and personal networks in credit relationships (Perlinge 2005, pp. I28-32).

The choice of the judicial district of Norra Möre for this case study is intentional. Norra Möre is located northwest of Kalmar, the most important trade and shipping centre in southeastern Sweden in the first half of the nineteenth century. Kalmar belonged to a group of cities entrusted by the state with exclusive privileges to import and export goods. Thanks to its large trade of wood products and iron bars, it became the fourth Swedish port by volume of exports, after Stockholm, Gothenburg and Gävle. Demographically, it was also one of the most dynamic areas of the country. In the 1840 os (before experiencing a sizeable wave of emigration in the second half of the century), Kalmar, with 6,300 inhabitants, was Sweden's seventh most populous city. The population of Norra Möre was twice as large, with more than I3, Ooo inhabitants.

The Norra Möre judicial district included eight parishes. On the coast north of Kalmar was the largest one, Ryssby, with its administration located in Rockneby; this also included the shipyard on the island of Skäggenäs. The smallest one was Kalmar Landsförsamling, which bordered the city. Agricultural activities were concentrated in Landsförsamlingen, Dörby, Kläckeberga and Förlösa. Forests and forestry dominated in Bäckebo and Kristvalla, as well as the inner parts of Åby and Ryssby. Here, fishing was also an important activity. ${ }^{3}$

During the period $\mathrm{I} 84 \mathrm{I}-5$, on average almost 60 per cent of the estates of deceased adults in Norra Möre were inventoried. In the city of Kalmar, the inventory frequency during the same period was only 40 per cent, a difference possibly explained by a higher poverty rate. Moreover, social control was greater and the distribution of property ownership more widespread in the rural areas. Still, even in comparison with

2 Initially one of the criteria was that 'parish bankers' offered deposit services. However, Perlinge decided to drop this since lending by individuals was largely based on substantial and long-lasting agricultural surpluses.

${ }^{3}$ Historiskt-Geografiskt och Statistiskt Lexikon över Sverige (1864), p. I65. 


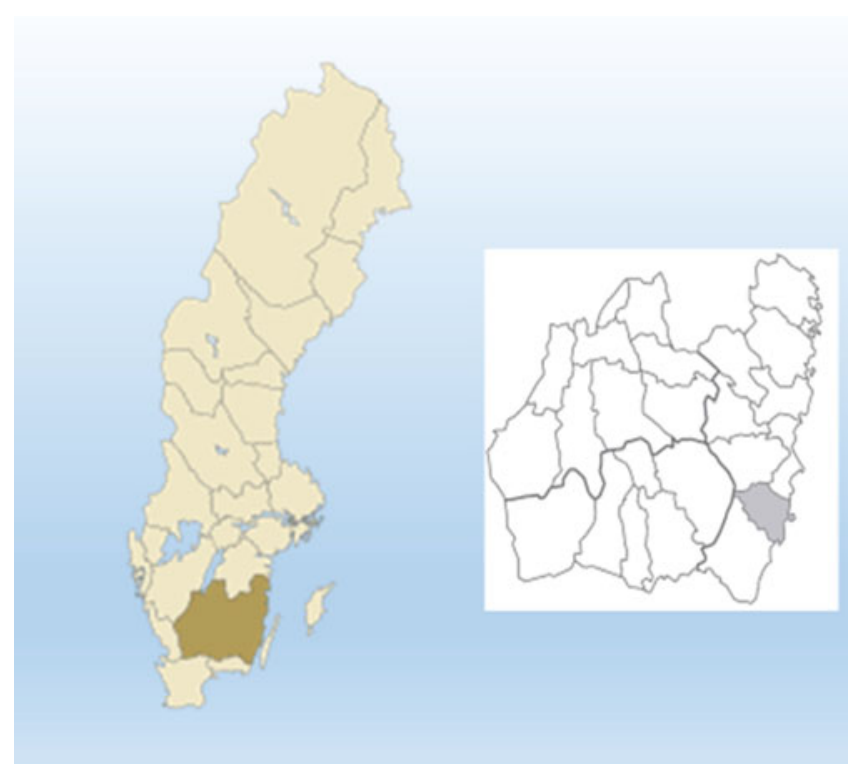

Figure I. The province of Småland in its Swedish setting (left) and the Norra Möre judicial district in its Småland provincial setting (right)

other rural areas, the inventory frequency was quite high in Norra Möre. For example, around the middle of the nineteenth century the rate was approximately 40 per cent in the parish of By in Bergslagen, and 43 per cent in the parish of Vånga in Scania (Isacson I979, pp. 2 IO-I; Lindgren 2002, p. 82 I; Perlinge 2005, p. 48).

Our estimation of total claims and debts of the economically active population in Norra Möre in the years $\mathrm{I} 84 \mathrm{I}-5$, based on 496 inventories, confirms that private informal credit dominated in rural Sweden even in the mid-nineteenth century. Despite the establishment in Kalmar of a savings bank in I83 I and a branch office of the Smålands Privat-Bank ('Smålandsbanken') in I 837 , households had virtually no bank savings in the first half of the I 840 os.

Two different types of private credits can be found in estate inventories: credits on current account (credit sales) and credits secured by written promissory notes (bonds). Private promissory notes were the main source of medium- and long-term credit, amounting to over 77 per cent of total claims. Hardly 2 per cent of total financial assets were liquid (cash, gold and silver), the remainder being represented by credits on current account and claims not supported by written promissory notes. As in the English case (Muldrew I998, p. I08, I I3), interest was generally charged on promissory notes but not on sales credits.

All of the 496 inventoried estates did not include financial assets. I focus exclusively on creditors with claims against promissory notes - that is, those involved in longerterm lending - the number of estates declines to I 87 . On average, each lender had 4.3 outstanding notes issued with a mean size of I 56 riksdaler riksgälds ( $\mathrm{rdr}$ rgs). The 
distribution, however, was very uneven, with a median of $50 \mathrm{rdr}$ rgs, equivalent to the price of an ox, the most common draught animal in that part of Sweden (Lindgren $20 \mathrm{I} 5$, pp. I I-I4). Of course it is impossible to trace back the provenience of reported claims. The largest promissory notes had their origin in estate divisions or real estate transactions, similar to what today we refer to as seller notes. Others had their roots in commercial transactions; in fact it is striking that many notes were for very small amounts, as low as the price of a kilogram of butter or cheese. Yet all claims represent a financial demand on the debtor's resources. In imperfectly monetized economies, like Sweden in the early I80os, it is to be expected that the transfer of goods was an important determinant of credit demand. Some of the credit suppliers in Norra Möre had, in addition to their agricultural activities, a very sizeable portfolio of financial claims spread among a large pool of debtors. These are the 'parish bankers' whom I focus on in the next sections.

\section{III}

In Swedish historiography the debate about the value of probate inventories as a source for historical research has focused mainly on (I) how accurate the records are in listing and valuing individual items, and (2) how representative the sample of preserved records is of the population of deceased individuals. In this article one aspect of this discussion, i.e. the valuation of real estate and moveable property compared to financial items, is especially relevant.

The most important single item in estate inventories was land or real estate. From I 8 I o onwards, all estates in Sweden were assessed for tax purposes every three years, and as a rule inventories relied on those assessments to report the value of land. In I 862 a reform of the tax system translated into a 300 per cent increase in the tax-based overall valuation of farm estates compared to the previous year (Utterström I957, pp. 607-9). ${ }^{4}$ This suggests that prior to the reform, and especially after the boom during the Crimean War of I854-7, estate inventories based on tax assessments tended to undervalue farm land with respect to market prices. Other studies, however, indicate that a sizeable differential between values reported in inventories and market prices had developed much earlier. Based on a large collection of local material from an agrarian region in central Sweden (more than 900 title deeds), Erikson (2015, pp. 42-5I) found that in the I830s market prices of farm estates were $30-40$ per cent above the values listed in estate inventories. In a similar vein, Isacson (I979, pp. 2II-I2) found that inventory values occasionally reported in probate inventories for the period I 840-60 were between 50 and 65 per cent of sales price in a parish situated in the mining and iron producing district of Bergslagen. In her study of inheritance strategies for land transfer in a parish in central Sweden in I8Io-45, Holmlund (2007, pp. I48-9) demonstrated that sales prices exceeded tax assessments by an average of 55 per cent in I8IO-45 and by

\footnotetext{
${ }^{4}$ See also Kommittébetänkande (I 859), pp. 74-80, Appendix D, E.
} 
almost 70 per cent in I 846-85. The inventories used for this study reveal similar discrepancies. On the few occasions when an estate had been acquired recently, the purchase price was 50-90 per cent higher than the tax assessments.

Moreover, Isacson (I979, pp. 220-5) demonstrated that even moveable property (both producer's capital and consumer goods) included in estate inventories was undervalued by approximately 25 per cent; in cases where property was sold at auction, the difference between inventory and sales prices was even greater. In his study of the city of Västerås for the period I776-I806, Montelius (I993, pp. $44 \mathrm{I}-53$ ) reached similar conclusions. Other studies, covering the period from the late I 700 to the early I900s, suggest the existence of differences of a comparable magnitude (between Io and 30 per cent) for cattle, grain and agricultural implements (Kuuse I980; Gadd I980). More recent research (Jonsson and Lilja 20I5; Nilsson et al. 20 I 5 ) provides additional evidence of undervaluation of inventoried items (especially in the case of goods frequently sold in the market), although for cloth and textiles in Västerås in the I880s inventory valuations and auction prices were reasonably close, with an undervaluation no higher than io per cent.

As far as financial assets reported in estate inventories are concerned, there exists a wide consensus on the fact that claims and debts were neither over- nor under-valued and were always reported at their nominal value. In the case of longer-term credits secured by written promissory notes, inventories also listed as a rule (although not always) the day of underwriting and the accumulated interest rate. In Sweden, the legislation that made estate inventories mandatory after decease dated back to I734. The main function of the inventory was to form the basis for the division of the estate among the deceased's heirs and to strengthen the position of creditors on their outstanding claims. For this purpose, the debts owed by the estate to various creditors, as well as the estate's assets, both material and financial, had to be determined. The existence of creditors and heirs increased the probability that an estate inventory was conducted and registered with the local courts. Against this background, it is reasonable to assume that those deceased individuals whose estates were not probated and inventoried most likely had no significant debts to report, otherwise some creditors presumably would have appeared to safeguard their claims. In fact recent research demonstrates that even individuals with modest real property (without real estate or financial claims and debts) are represented among inventoried estates. In his study of Vånga parish in northeastern Scania, Perlinge (2005, pp. II4-I7) finds that about half of all deceased adults left inventoried estates during the second half the nineteenth century. The great majority of omissions - up to 86 per cent - can be explained by the estimated poverty rates. In other words, those whose estates were not inventoried as a rule had neither debts nor any worthwhile assets to be accounted for.

\section{IV}

In order to examine in detail the composition of financial portfolios of individuals who could be regarded as parish bankers, the study will now focus on the five 
largest creditors in Norra Möre. The records show that lending was highly concentrated in the hands of a small number of credit suppliers. Limiting the study to the promissory note market - which can be considered as the 'true' market for private credit - the estate material lists I 87 deceased creditors who left a total of 807 outstanding notes. The total sum amounted to I26,000 rdr rgs, of which the ten largest creditors accounted for more than half and the 25 largest for almost three-quarters. The five largest creditors accounted for 38 per cent of the outstanding claims against promissory notes (see Table I).

Peter Persson (Söregärde farm)

By far the largest lending business was that of the freehold farmer in Söregärde. At his death at age 7I, his estate inventory listed 47 outstanding notes divided among 43 different borrowers, for a total value close to $20,000 \mathrm{rdr}$ rgs. He owned and cultivated a large farm on so-called privileged or noble land, which could be obtained by commoners by law after I 8 IO and was exempt from payments to the state.

Anna Greta Andersdotter and Jan Olsson (Rugstorp farm)

Married to freeholder Jan Olsson of Rugstorp farm, Anna Greta Andersdotter died very young, at age 28 , in January $\mathrm{I} 842$. As required by the probating procedure, assets and liabilities of the whole household had to be listed in the inventory when a marriage was dissolved by death. Legal positions and property rights varied according to social status, and married women were still subordinated to their husbands in legal and economic matters. The Rugstorp property was an old family homestead that had been inherited through at least four generations on the male side. Claims of around 9,000 rdr rgs made the estate one of the most important credit providers of the Norra Möre district. Only about a year before Anna Greta's death, however, the farm was sold. Most of the payment (for the considerable sum of 7,500 rdr rgs) consisted of a seller's note with added interest. In the following analysis this note is excluded, but still the extent of the Rugstorp credit provision seems powerful. The remaining promissory note claims reach I, 3 I 8 rdr rgs, distributed among I 2 different borrowers and with a large presence in neighbouring parishes.

Cajsa Nilsdotter and Peter Nilsson (Ingelsryd farm)

Married to homestead owner Peter Nilsson, Cajsa Nilsdotter died in December I 842 at their farm, Ingelsryd. The family was well established in the community. Peter was appointed a village elder and assumed, like his father and later his son (who took over the agricultural activities), the prestigious position of juror in the local judicial district.

Maria Nilsdotter and Peter Jonsson (Törnerum and Nöbble Manor farms)

Törnerum was a noble manor, owned during the I 840 os by Baron Claes Gustaf Raab. The cultivation of Törnerum was in the hands of a lessor, Peter Jonsson, and his wife Maria Nilsdotter. When Maria died in I 843, the couple were also leasing an additional large farm in the parish, Nöbble Manor. Peter had initiated a kind of leaseholder career by successively seeking out new and more demanding properties to rent. He ended his life as country gentleman and owner of Nöbble Manor. He 
Table I. The five largest creditors in the note lending market in Norra Möre, 1841-5

\begin{tabular}{|c|c|c|c|c|c|c|}
\hline $\begin{array}{l}\text { Amount } \\
\text { rdr rgs }\end{array}$ & $\begin{array}{c}\text { Market } \\
\text { inventoried } \\
\text { estates }\end{array}$ & $\begin{array}{l}\text { re of } \\
\text { district } \\
\text { estimated }\end{array}$ & $\begin{array}{c}\text { Number of } \\
\text { borrowers }\end{array}$ & $\begin{array}{l}\text { Deceased, age } \\
\text { village, parish }\end{array}$ & Spouse, age & Date of inventory \\
\hline I9,794 & I 5.7 & I. 8 & 43 & $\begin{array}{l}\text { Peter Persson, 7I, } \\
\text { Söregärde, Ryssby }\end{array}$ & $\begin{array}{l}\text { Maja Stina Anders- } \\
\text { dotter, } 30\end{array}$ & $5 / 7 / 1844$ \\
\hline 8,824 & 7.0 & 0.8 & $\mathrm{I} 3$ & $\begin{array}{l}\text { Anna Greta Andersdtr, } \\
28 \text {, Rugstorp, Ryssby }\end{array}$ & Jan Olsson, 33 & $\mathrm{I} 7 / 2 / \mathrm{I} 842$ \\
\hline 8,042 & 6.4 & 0.7 & 34 & $\begin{array}{l}\text { Cajsa Nilsdotter, 54, } \\
\text { Ingelsryd, Kristvalla }\end{array}$ & Peter Nilsson, 52 & $8 / 3 / 1843$ \\
\hline 6,598 & 5.2 & 0.6 & 80 & $\begin{array}{l}\text { Maria Nilsdotter, 4I, } \\
\text { Törnerum, Ryssby }\end{array}$ & Peter Jonsson, 4I & $6 / 7 / 1843$ \\
\hline 4,559 & 3.6 & 0.4 & 37 & $\begin{array}{l}\text { Jonas Carlsson, 53, } \\
\text { Svensboryd, Bäckebo }\end{array}$ & $\begin{array}{l}\text { Maja Lisa Carlsdotter, } \\
\text { 50 }\end{array}$ & $9 / 3 / 1842$ \\
\hline $47,8 \mathrm{I} 7$ & 37.9 & $4 \cdot 3$ & 207 & $\ldots$ & $\ldots$ & $\ldots$ \\
\hline
\end{tabular}

Sources: Norra Möre häradsrätts arkiv, bouppteckningar I84I-5, series F II a, VaLa. 
came from a relatively well-off leasing family. His father leased and cultivated two sizeable farms in the parish. After his father's death in I8 I5 Peter's mother married another new lessor, and Peter moved as a worker and overseer to Björnö Manor. In I 825, he married the daughter of a lessor in Stojby and took over his father-inlaw's lease. Four years later, he assumed the lease to Törnerum, and in I 838 complemented this with another lease on Nöbble Manor.

Jonas Carlsson (Svensboryd farm)

In I 842 when Jonas Carlsson of Svensboryd died, the transfer of the farm to the next generation had already been accomplished. The transfer was facilitated by the fact that only one of the two daughters remained alive, married to a farmer from Bäckebo village. Judging by all the positions of trust that Jonas Carlsson received during his lifetime, he was a well-known and respected person in the local community. Like his predecessor at the farm, he had been a churchwarden in the parish and for many years the village elder as well. When the Svensboryd farm was transferred to the daughter and sonin-law, a long tradition was followed in the family enterprise. Jonas Carlsson had himself gained possession of the farm through marriage, and his father-in-law had also obtained the farm through marriage. The farm in Svensboryd was thus a true family property inherited on the female side and transmitted across generations.

\section{$\mathrm{V}$}

As discussed in Section III, real assets were substantially undervalued in estate inventories. In order to avoid overstating the weight of financial assets, the inventory valuations of the farm and its physical wealth (household and capital goods) reported in Table 2 have been adjusted upward by 50 and 33 per cent respectively. In the two cases when the real assets were transferred or sold shortly before the death, the transfer or market price was used and the remaining debt was subtracted from the financial assets.

In specific cases different reasons may explain why financial assets vary between various points in time. However, we can detect some common characteristics among the estates reporting the most substantial lending activities. For all five farms identified as 'parish bankers', the value of outstanding financial claims represented the largest share of their total gross wealth (close to 75 per cent in once case, and over 50 per cent in another one), and their value exceeded the value of real estate and productive capital. Also, the weight of account balances was negligible, while claims secured by promissory notes were the dominant form of credit. As their financial liabilities were small, they all had a substantial positive financial net wealth.

It is interesting to note that a substantial portion of their outstanding liabilities were debts owed to minors with inherited assets - so-called child inheritance funds or guardian funds. In pre-industrial societies it was not only infant mortality that was high: many parents died relatively young, leaving children who had to be cared for. In Sweden, outside the capital city of Stockholm, local courts had to appoint a 
Table 2. Major components of wealth: parish bankers of Norra Möre 1841-5 (rdr rgs and percentage of gross wealth)

\begin{tabular}{|c|c|c|c|c|c|c|}
\hline & \multicolumn{2}{|c|}{ Söregärde } & \multicolumn{2}{|c|}{ Rugstorp } & \multicolumn{2}{|c|}{ Ingelsryd } \\
\hline & rdr rgs & $\%$ & rdr rgs & $\%$ & rdr rgs & $\%$ \\
\hline Real estate & 6,320 & 22.6 & $7,500^{\mathrm{b}}$ & 78.3 & 8,300 & 44.7 \\
\hline Household goods & 622 & 2.2 & 432 & 4.5 & 556 & 3.0 \\
\hline Producer's capital & 547 & I.9 & 205 & 2.I & $\mathrm{I}, 543$ & I8.9 \\
\hline Financial assets & 20,503 & $73 \cdot 3$ & $\mathrm{I}, 444$ & I5.I & $8, \mathrm{I} 48$ & $43 \cdot 9$ \\
\hline of which promissory notes & I9,794 & & I, 3 I 8 & & $8, \mathrm{I} 48$ & \\
\hline Gross wealth & 27,992 & 100 & $9,58 \mathrm{I}$ & Ioo & I 8,547 & 100 \\
\hline Liabilities & 235 & 0.8 & $\mathrm{I}, 263$ & $\mathbf{I 3 . 2}$ & o & \\
\hline of which guardianship & o & & 377 & & - & \\
\hline \multirow[t]{2}{*}{ Net wealth } & 27,757 & 99.2 & 8,3 I 8 & 86.8 & I 8,547 & 100 \\
\hline & \multicolumn{3}{|c|}{ Törnerum } & \multicolumn{2}{|c|}{ Svensboryd } & \\
\hline Real estate & $825^{\mathrm{a}}$ & 6.3 & & $7,000^{b}$ & $54 \cdot 3$ & \\
\hline Household goods & 880 & 6.7 & & 483 & 3.7 & \\
\hline Producer's capital & 4,460 & 33.8 & & 582 & $4 \cdot 5$ & \\
\hline Financial assets & 7,016 & 53.2 & & 3,787 & 29.4 & \\
\hline of which promissory notes & 6,598 & & & $3,5 \mathrm{I} 7$ & & \\
\hline Gross wealth & $\mathrm{I} 3, \mathrm{I} 8 \mathrm{I}$ & 100 & & $\mathrm{I} 2,895$ & 100 & \\
\hline Liabilities & $\mathrm{I}, 674$ & $\mathbf{1 2 . 7}$ & & 387 & 3.0 & \\
\hline of which guardianship & $\mathrm{I}, \mathrm{I} 67$ & & & I 50 & & \\
\hline Net wealth (of gross wealth) & I I ,507 & $87 \cdot 3$ & & $\mathrm{I} 2,508$ & 97.0 & \\
\hline
\end{tabular}

Note: Real estate values adjusted upwards by 50 per cent; household goods and producer's capital by 33.3 per cent (see text).

a tenant farmer being the proprietor of a crofter's holding

b selling price at preceding transaction

Source: Norra Möre häradsrätts arkiv, bouppteckningar I84I-5, series F II a, VaLa.

guardian in charge of managing the inherited assets, if any, until the child reached the age of legal majority. A guardianship was regarded as a civic duty and entrusted to those who were considered trustworthy and economically solvent figures in the local society. Guardians had to report to the court on their management of the child inheritance funds, but were free to decide how to administer them (Bengtsson 2002, pp. 89-90; Ighe 2007, pp. 52, 82-5, I25-35, I45-6).

The presence of liabilities related to guardianships in Table 2 indicates that the debtor was considered a trustworthy person in the community. Peter Jonsson, the lessor of Törnerum and Nöbble Manors, had been appointed guardian for two minor children, the son of a farmer and the daughter of a crofter on the land of the manor, whose parents had died. The estate inventories of Rugstorp and Svensboryd also report the existence of child inheritance funds among their debts. 
It is not surprising that those who acted as private bankers in the local community also could serve as guardians for minors and administer their funds, either by lending them out on the credit market or by investing them in agricultural activities.

In an estate inventory of a self-sufficient peasant household it is quite difficult to separate productive farm capital from consumption goods. Nevertheless, Table 2 presents a rough disaggregation in order to study the relation between productive capital and household goods. Household equipment includes glass and earthenware, copper and iron items, furniture, bedding, non-working clothes and books. Livestock, grain inventories, wagons, fishing, blacksmith and harness equipment, as well as 'various' items such as work benches and storage facilities are counted as agricultural working capital.

Two of the estates reported an agricultural working capital lower than consumption goods. To some extent, this result is a consequence of the on-going reduction in agricultural activity when the deaths occurred. Large categories listed under agricultural capital included working animals, cows and sheep. In the case of Rugstorp the property had already been sold and the remaining livestock much reduced compared with other farms of similar size; the numbers are also reduced compared with older inventories for Rugstorp itself. The privileged farm of Söregärde had partly been rented out during the last five years of the proprietor's life to a so-called sharecropper. The value of the stock of animals on the farm had been halved in the I 844 estate inventory compared to those of 1836 and I $835 .{ }^{5}$

The estate inventory for Törnerum and Nöbble stands out for having a very large amount of productive agricultural capital. The leaseholder of the two manors had invested in a large quantity of livestock that amounted to one-third of the reported gross wealth. In addition to steers, heifers, calves and hogs, the inventories reported seven horses, 2 I oxen, 36 cows, two bulls and 57 sheep. The real estate listed in the inventories was a newly purchased crofter's holding. ${ }^{6}$

As mentioned above, the largest share of credits in the estate of Rugstorp was a seller's note from the recently completed sale of the homestead. Other financial assets amounted to only is per cent of the total gross wealth before the sale. It is clear that the financial activity at Rugstorp was less extensive than in the other estates, although the same basic characteristics can be found here as well: the prevalence of lending against notes, small or insignificant debts and a relatively modest amount of capital invested in the agricultural activity itself.

\section{I}

The existing literature on informal credit markets in rural societies emphasizes their local character. In itself, that is hardly surprising. The private credit market was to a

5 Norra Möre häradsrätts arkiv, bouppteckning F II:33, pp. 207-I4; F II:20, pp. IO3 I-42; F II:34, pp. 45I-65; F II:30, pp. 607-25; F II:29, pp. 74I-63.

6 Norra Möre häradsrätts arkiv, bouppteckning F II:33, pp. I247-67. 
Table 3. The lending of parish bankers: Norra Möre 1841-5: geographical distribution of promissory loans ( $r d r$ rgs and percentage)

\begin{tabular}{|c|c|c|c|c|c|c|}
\hline \multirow[t]{2}{*}{ Client domicile } & \multicolumn{2}{|c|}{ Local parish } & \multicolumn{2}{|c|}{ Adjoining parishes } & \multirow{2}{*}{$\begin{array}{l}\text { Total } \\
\text { rdr rgs }\end{array}$} & \multirow{2}{*}{$\begin{array}{c}\text { Number of } \\
\text { clients }\end{array}$} \\
\hline & rdr rgs & $\%$ & rdr rgs & $\%$ & & \\
\hline Söregärde & 10,522 & 53.2 & 9,272 & 46.8 & I9,794 & 43 \\
\hline Rugstorp $^{a}$ & 924 & 70.1 & 394 & 29.9 & I, 3 I 8 & I 2 \\
\hline Ingelsryd & 7,660 & 95.2 & 382 & 4.8 & 8,042 & 34 \\
\hline Törnerum & 3,479 & 52.7 & I,467 & 22.2 & 6,598 & 80 \\
\hline Svensboryd $^{\mathrm{a}}$ & 2,739 & $77 \cdot 9$ & $32 \mathrm{I}$ & 9.1 & $3,5 \mathrm{I} 7$ & 36 \\
\hline Total & 25,324 & 64.5 & I I, 836 & 30.I & 39,269 & $20 \mathrm{I}$ \\
\hline
\end{tabular}

a seller's notes and inheritance credit of property excluded

Source: Norra Möre häradsrätts arkiv, bouppteckningar I 84I-5, series F II a, VaLa.

large extent based on trust, so that the lender could take it for granted that the borrower would meet his obligations. In the local community the credit worthiness of individuals and households was common knowledge. The concentration of private lending in the 'hood' has been observed in Schleswig in the seventeenth century as well as in France and Sweden during the eighteenth century, and continued to be common in rural areas during the nineteenth century (Rasmussen 2010, pp. 85-9I; Dermineur 2015, pp. 495-9; Olsson and Svensson 2013, pp. 218-25; Perlinge 2005, pp. I29-32).

We find the same pattern in Norra Möre (see Table 3). In the case of loans based on promissory loans, a majority of the borrowers were located in the local parish (6o per cent).

An additional third of the loans was granted to borrowers from neighbouring parishes, while only 8 per cent was advanced to persons living outside the district. The variation among the parish bankers, however, was great. The lessors of Törnerum and Nöbble Manors had a considerably larger pool of borrowers compared to the other parish bankers, as their estate inventory listed no less than 80 debtors. Moreover, 25 per cent of the outstanding amount was lent outside the district, including the island of Öland and the cities of Kalmar and Mönsterås. Söregärde farm was the second largest credit provider (43 borrowers), closely followed by Svensboryd (36) and Ingelsryd (34). Their loan structure, however, varied considerably. Söregärde provided very large individual loans, while the notes in the Ingelsryd portfolio were for smaller sums. The median amount per borrower was 384 and $54 \mathrm{rdr}$ rgs respectively. In turn, no financial relationships between residents of the city of Kalmar and the surrounding countryside can be detected in the activities of the parish bankers, with the exception of one loan by the Törnerum estate to a merchant in Kalmar.

What was the social composition of borrowers? It is important to stress at the outset that the credit market in Norra Möre was a male preserve. In the few cases in which women are recorded as borrowers, they were all widows - a condition that allowed 
Table 4. The lending of parish bankers: Norra Möre 1841-5: distribution of borrowers by social group ${ }^{a}$ (rdr rgs, percentage, number of clients, mean value per client)

\begin{tabular}{lrrrr}
\hline \hline Social group & Rdr rgs & $\%$ & No. & $\begin{array}{c}\text { Mean value } \\
\text { rdr rgs }\end{array}$ \\
\hline Persons of rank & I, 545 & 3.9 & 6 & I 66 \\
Craftsmen & I,447 & 3.7 & I 4 & 47 \\
Farmers & 30,588 & 77.9 & I IO & I6I \\
Crofters & $2,33 \mathrm{I}$ & 5.9 & 35 & 25 \\
Farmhands & 2,444 & 6.3 & 22 & 25 \\
Non-identified & 9 I 4 & 2.3 & I 4 & 55 \\
Total & $\mathbf{3 9 , 2 6 9}$ & I00 & $\mathbf{2 0 I}$ & $\mathbf{6 5}$ \\
\hline \hline
\end{tabular}

a seller's notes and inheritance credit of property excluded

Source: Norra Möre häradsrätts arkiv, bouppteckningar I84I-I 5, series F II a, VaLa.

them to achieve legal majority. Thanks to the extreme granularity that characterizes Swedish demographic data of this period, names and residence records could be used to identify most of the borrowers and occupational titles could be used to reconstruct their social structure. As shown in Table 4, only in very few cases is the social position of borrowers unknown. 'Persons of rank' is a category used in Swedish population statistics (standspersoner) that includes military officers, vicars, postal inspectors and other officials - either nobles or commoners - belonging to the local administrative elite. The farmer category includes both tenants on large rented farms and freeholders (besuttna), while crofters are small, non-propertied farmers on non-taxed farmland. Farmhands include all handicraft workers, sailors and household employees but also those relatively wealthy freeholders who worked as female or male farmhands for some years before marriage. Table 4 suggests that the private market for note-based loans operated by our parish bankers was principally a market for the well-off. No less than 82 per cent of borrowers were 'persons of rank' and 'farmers'. Compared to their share in the population, farmers' households were definitely overrepresented. This is hardly surprising. As the supply of private credit in the agricultural sector was heavily based on local knowledge, trust and personal networks, the property of landowning farmers increased their creditworthiness and made it easier for them to recruit loan guarantors compared to crofters and farmhands.

Looking more closely at the lending policies of the various parish bankers reveals interesting differences with regard to the borrowers' social standing. Table 5 compares the largest 'banking firm' in Söregärde - with a total level of note-based lending approaching 20,000 rdr rgs distributed among 43 borrowers - with Törnerum/ Nöbble. The latter reported a considerably larger number of borrowers (80), but a smaller total amount of credit issued (6,600 rdr rgs). A number of circumstances suggest that the leaseholder of Törnerum/Nöbble should be included in the top 
Table 5. The lending of Söregärde and Törnerum 1841-5: distribution of borrowers by social group (rdr rgs, percentage, number of clients, mean value per client)

\begin{tabular}{|c|c|c|c|c|c|c|}
\hline & \multicolumn{3}{|c|}{ Söregärde } & \multicolumn{3}{|c|}{ Törnerum } \\
\hline & Rdr rgs & $\%$ & No. & Rdr rgs & $\%$ & No. \\
\hline Persons of rank & 762 & 3.8 & 2 & $45 \mathrm{I}$ & 6.8 & 2 \\
\hline Craftsmen & 238 & $\mathrm{I} .2$ & 2 & 979 & I 4.9 & 8 \\
\hline Farmers & I6,243 & $82 . \mathrm{I}$ & $3 \mathrm{I}$ & 3,208 & 48.6 & 25 \\
\hline Crofters & 708 & 3.6 & 3 & 832 & I 2.6 & 22 \\
\hline Farmhands & I,79I & 9.0 & 4 & 525 & 8.0 & I4 \\
\hline Non-identified & 52 & 0.3 & I & 603 & 9.I & 9 \\
\hline Total & I9,794 & IOO & 43 & 6,598 & IOO & 80 \\
\hline
\end{tabular}

Source: Norra Möre häradsrätts arkiv, bouppteckningar I 84I-5, series F II a, VaLa.

social layers of the district; for instance, in his inventory household goods represented a much larger share of total wealth compared to other parish bankers (see Table 2). In addition to engaging in financial transactions over a larger geographical area, he made also substantial loans to individuals of lower social standing. Credits to freeholders owning or leasing their own farms constituted less than half of their total lending. This is in contrast to Söregärde, where they amounted to more than four-fifths. In the case of Törnerum/Nöbble, the rest of the loans were evenly distributed among local craftsmen (I 5 per cent), cottagers (I 3 percent) and farm workers (8 per cent). All of these were, however, individuals subordinate to or employed by the manors. As it is much more difficult to identify individual farmworkers than established farmers in the population records, the large share (Io per cent) of unidentified borrowers in their case could be added to the 'farm worker' category, which further reinforces the 'democratic' characteristics of Törnerum/Nöbble lending.

\section{VII}

Four of the parish bankers were freeholders who had lived and worked on the same property for generations. This continuity creates a unique opportunity to study the importance of lending in the farm households' activities over time. For that purpose, we relied on previous inventories conducted on these estates to estimate the share of financial assets as a proportion of total gross wealth at various points in time (see Table 6).

As previously noted, the leaseholder Peter Jonsson of Törnerum and Nöbble Manors came from a prosperous leaseholding family in the parish. He was only I 2 years old when his father died in I8 I 5 . On the base of the estate inventory conducted on that occasion, the weight of financial business was negligible at the time of his father's death. A more detailed examination of the estate inventory, 
Table 6. Intergenerational importance of finance capital among Norra Möre parish bankers of the 1840 s

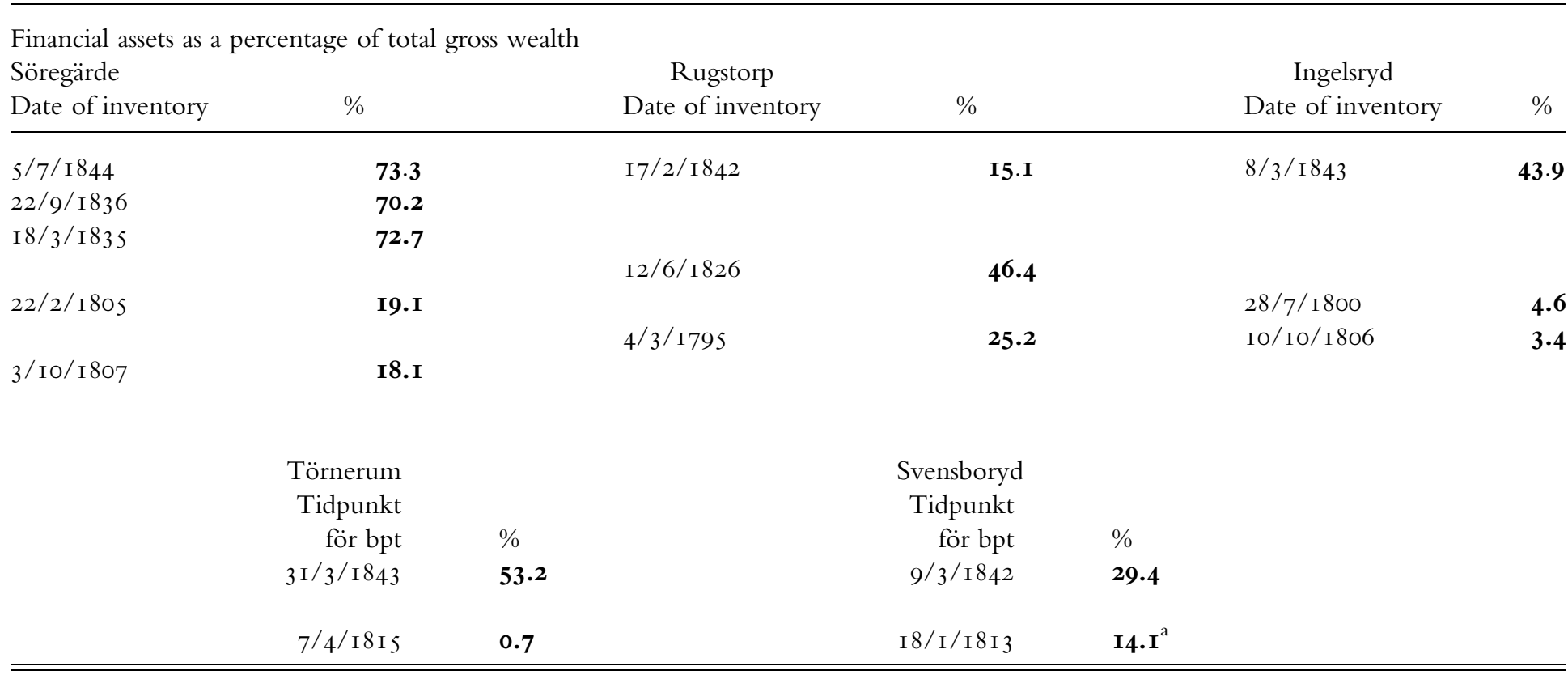

Note: Real estate values adjusted upwards with 50 per cent; household goods and producer's capital with 33 per cent (see text)

${ }^{a}$ I 2.7 per cent were loans to daughters, sons and sons-in-law.

Sources: Norra Möre häradsrättsarkiv, bouppteckningar I795-I845, F II a: 4, 6, 9, I0, I4, I5, 20, 29, 30, 33, VaLa. 
however, raises doubts about such a conclusion. At the time of his death in $\mathrm{I}_{8} \mathrm{I} 5$, his father was still listed as the leaseholder of two large farms in the villages of Ljungnäs and Hultsby, but he had also recently acquired a tax unit of land on the island of Öland valued at I, I67 rdr rgs. The total debt listed in the inventory amounted to I,4 I $5 \mathrm{rdr}$ (equal to 45 per cent of the gross assets). More than half of it consisted of unpaid lease fees in the previous two years and guardian funds administered; the remaining debts were auction payments and some very minor items. The reported debts do not suggest that the Öland purchase was financed by loans. Thus the possibility that financial assets were liquidated to pay for the parents' farm acquisition cannot be excluded. What can be definitely asserted on the basis of the source material, however, is that Peter Jonsson's father appears to have been a trusted and respected person since he was entrusted both to hold auctions and to serve as guardian for minor children. ${ }^{7}$

The volume of lending extended by Söregärde farm can be determined by several listings in the estate inventory material during the ten years preceding the inventory of I 844. As is apparent from the Table 6 , the moneylending activity was a very important component of the total business activity during the entire period, with a share of total assets exceeding 70 per cent. Debts were virtually non-existent, as they amounted to less than I per cent of gross assets. A comparison can be made with the same tax unit in I 805, when Peter Persson's first wife inherited the farm, and the situation on his parents' farm when his mother died in I807. In both cases, the estate was practically debt free and financial assets amounted to approximately 20 per cent of total assets; this clearly suggests that financial transactions were an important component in the business activities of the previous generation.

Also in the case of Rugstorp the evidence suggests that the lending business was considerable in previous generations, even greater than in 1842 . When the farm was transferred from one generation to the next in 1826 , the estate inventory included a very substantial list of debtors. Nineteen borrowers owed an amount equal to almost half the estate's total assets, which included no debts whatsoever. Going back to yet another generational transfer in $\mathrm{I} 795$, a similar pattern emerges, as lending amounted to a quarter of the assets and the negligible debts listed were vis-à-vis the sons.

Thus we can conclude that three of the largest credit providers in the district during the I 840s (Törnerum, Söregärde and Rugstorp) might be regarded as local 'financial dynasties'. The remaining two (Ingelsryd and Svensboryd), however, lacked any tradition of moneylending from earlier generations. At Ingelsryd, inventories conducted in I 800 and I 806 suggest that financial assets were small and consisted mainly of silver objects. The debts were also negligible while the productive capital and the stock of farm animals were relatively large. It is true that financial assets made up almost i 5 per cent of the total wealth in the estate inventory for Svensboryd in I8 I 3 , but most of this credit had been granted to family members (daughters, sons-in-law and sons) in the form of cash and in-kind loans to start a family or purchase property. In both cases past

\footnotetext{
7 Norra Möre häradsrätts arkiv, bouppteckning F II: I 5, pp. I65-79.
} 
estate inventories convey an impression of well-managed agricultural properties with a focus on production rather than on financial business.

\section{VIII}

This article has studied a private, informal and lively credit market in rural Sweden during the I840s using probate inventories from the judicial district of Norra Möre. The market was mainly based on the issue of private promissory notes for medium- and long-term loans; these claims were found in 37 per cent of the c. 500 probate inventories analysed. The denomination of notes varied greatly, ranging from very large amounts to fund real property transactions to rather tiny sums. The main suppliers of credit based on promissory notes were wealthy individuals who specialized in lending. The business of the five largest farm households classified as 'parish bankers' have been subjected to closer scrutiny in this article.

A common characteristic was that they were well-established and relatively prosperous farm families, who had traditionally occupied relevant positions in the local community as village and church elders, jurors in the local court, guardians of minor children's inheritance funds, and auctioneers. Their financial assets exceeded the value of real estate and other capital assets (livestock, equipment and inventories), even after adjusting upwards the value of the latter to correct for their typical undervaluation with respect to their market prices, while their financial liabilities (other than debts arising from their role as guardians of inheritance funds) were negligible.

Similarly to other case studies of local credit networks in modern Europe, the market in Norra Möre was based on mutual trust and an intimate knowledge of the creditworthiness of borrowers. The market was to a large extent reserved for the well-off male farmers, regardless of whether they owned their farms or leased taxed land. More than three- fourths of the parish bankers' borrowers were farmers. Adding 'persons of rank', nobles as well as commoners, to this figure, almost 82 per cent of the outstanding credit was extended to the economically and socially well-to-do groups in the local society. Interesting differences, however, existed between the lending policies of the freeholders and the leaseholder of the two manors of Törnerum and Nöbble, who lent considerably more money to the landless social groups (mainly individuals subordinate to or employed by the manors) compared to the other parish bankers.

Finally, the ratio of financial assets to total wealth was reconstructed on the basis of estate inventories of earlier generations to explore the possible existence of longstanding family traditions of financial business among the five parish bankers studied. Of course, the probate inventories can provide only limited evidence, as a wide array of idiosyncratic reasons may have influenced the composition of these households' wealth at different points in time. This makes a comparison across different generations inherently elusive. However, in two cases (the Söregärde and Rugstorp families) the evidence suggests with reasonable certainty that lending was 
also an important part of the previous generation's business activity, so that in the local context they could have been considered 'financial dynasties'. However, this was less a matter of intergenerational succession (as in the experience of modern family firms) than a consequence of diversification of economic activities deeply embedded in agricultural pursuits. Moreover, financial business was highly dependent on the lifespan of the family head, since outstanding promissory notes were expected to be repaid or reissued in case of death.

As usual, the findings of this study open the door to new questions. Was the concentration of private lending in the hands of a small number of 'parish bankers' a consequence of the increasing monetization, intensified agricultural investment and a fast-expanding market for agricultural property that preceded the rise of commercial capitalism and industrialization? Or was it as old as the production and exchange of goods, but organized differently in different epochs? We leave these questions to future research.

Submitted: 6 September 2016

Revised version submitted: 27 January 2017

Accepted: 24 February 2017

First published online: 2 May 2017

\section{Sources}

Landsarkivet i Vadstena (VLA):

Bouppteckningar Norra Möre häradsrätt, serie F II a, I 795-I887.

Död- och begravningsböcker: Bäckebo, Dörby, Förlösa, Kalmar Landsförsamling, Kläckeberga, Kristvalla, Ryssby and Åby parishes, I795-I 887 .

Husförhörslängder: Bäckebo, Dörby, Förlösa, Kalmar Landsförsamling, Kläckeberga, Kristvalla, Ryssby and Åby parishes, I790-I890.

Kommittébetänkande för upprättande av förslag till ny författning angående utgörande av allmänna bevillningen till Kungl. Maj:t. (1859)

Historiskt-Geografiskt och Statistiskt Lexikon över Sverige, vol. 5. Stockholm: Hammars. (I 864)

\section{References}

AHLBERGER, C. (1988). Vävarfolket. Hemindustrin i Mark 1790-1850. Dissertation, Gothenburg University, Institutet for lokalhistorisk forskning, I.

BENGTSSON, T. (2002). Why dad dies: the mortality of men in their working ages in the I8th and I9th centuries. In R. Derosas and M. Oris (eds.), When Dad Died: Individuals and Families Coping with Family Stress in Past Societies. Bern and New York: Peter Lang.

DERMINEUR, E. (2015). Trust, norms of cooperation, and the rural credit market in eighteenthcentury France. Journal of Interdisciplinary History, 45, pp. 485-506.

ERIKSON, M. (2015). Mälardalsbönders skulder I770-I 870. Mimeographed paper, 2 I Dec., Uppsala University, Department of Economic History.

GADD, C-J. (I980). Swedish probate inventories, I750-I860. In A. van der Woude and A. Schuurman (eds.), Probate Inventories: A New Source for the Historical Study of Wealth, Material Culture and Agricultural Development. Utrecht: HES Publishers.

GELDERBLOM, O., JONKER, J. and KOOL, J. C. M. (20I6). Direct finance in the Dutch Golden Age. Economic History Review, 69(4), pp. I $778-98$.

HELLGREN, H. (2003). Fasta förbindelser. En studie av låntagare hos sparbanken och informella kreditgivare $i$ Sala 1860-1910. Uppsala Studies in Economic History, 66. Uppsala: Acta Universitatis Uppsaliensis. 
HOFFMAN, P., POSTEL-VINAY, G. and ROSENTHAL, J-L. (200o). Priceless Markets: The Political Economy of Private Credit in Paris 1660-1870. Chicago: University of Chicago Press.

HOLDERNESS, B. A. (I976). Credit in English rural society before the nineteenth century, with special reference to the period I650-I720. Agricultural History Review, 24, pp. 97-IO9.

HOLMLUND, S. (2007). Jorden vi ärvde. Arvsöverlåtelser och familjestrategier på den uppländska landsbygden 1810-1930. Stockholm Studies in History 88. Stockholm: Acta Universitatis Stockholmiensis.

IGHE, A. (2007). I faderns ställe. Genus, ekonomisk förändring och den svenska förmyndarinstitutionen ca 1700-1860. Publications of the Department of Economic History, 99. Gothenburg: School of Business, Economics and Law.

ISACSON, M. (I979). Ekonomisk tillväxt och social differentiering 1680-1860. Bondeklassen i By socken, Kopparbergs län. Stockholm: Almqvist \& Wiksell.

JONSSON, P. and LILJA, K. (2015). Rätt pris? Kläder och textilier i bouppteckningar och på auktioner. Mimeographed paper for the Eleventh Economic History Meeting, Umeå University, 9-Io Oct.

KUUSE, J. (I980). The Swedish probate inventories as a source for research in economic and social history. In A. van der Woude and A. Schuurman (eds.), Probate Inventories: A New Source for the Historical Study of Wealth, Material Culture and Agricultural Development. Utrecht: HES Publishers.

LILJA, K. (2004). Marknad och hushål. Sparande och krediter i Falun 1820-1910 utifrän ett livscykelperspektiv. Uppsala Studies in Economic History, 7I. Uppsala: Acta Universitatis Uppsaliensis.

LINDGREN, H. (2002). The modernization of Swedish credit markets, I840-I905: evidence from probate records. Journal of Economic History, 62, pp. 8 Iо-32.

LINDGREN, H. (20I5). Till stärkande av den enskilda crediten... Räkningskrediter och reverslån i det agrara lokalsamhället på I 840-talet. Stockholm School of Economics Working Paper Series in Economic History, 2015:3.

MONTELIUS, S. (I993). Metropol i Mälardalen: Västerås ekonomiska historia 1620-1860, vol. 2. Västerås.

MULDREW, C. (I998). The Economy of Obligation: The Culture of Credit and Social Relations in Early Modern England. London: Macmillan.

NILSSON, R., ULVÄNG, G. and MURHEM, S. (20 I 5). Boupptecknings-värde och marknadsvärde i städer och på landsbygd under I700- och I80o-talen. Mimeographed paper for the Eleventh Economic History Meeting, Umeå University, 9-1o Oct.

OLSSON, M. and SVENSSON, P. (20 I3). Production and credits. A micro-level analysis of the agrarian economy in Västra Karaby parish, Sweden, I786-I846. In E. Hillbom and P. Svensson (eds.), Agricultural Transformation in a Global History Perspective. London and New York: Routledge.

PERLINGE, A. (2005). Sockenbankirerna. Kreditrelationer och tidig bankverksamhet. Vånga socken $i$ Skåne 1840-1900. Nordiska museets handlingar, I30. Stockholm: Nordiska museets förlag.

RASMUSSEN, C. P. (2010). Gaeld i Gram herred. Lån, kredit og pengeökonomi i det nordlige Sönderjylland för og efter katastrofen I657-60. Historisk Tidsskrift, II0, pp. 77-I I6.

SVENSSON, P. (200I). Agrara entreprenörer. Böndernas roll i omvandlingen av jordbruket $i$ Skåne ca 1800-1870. Lund Studies in Economic History, I6. Lund.

SVENSSON, P. (2004). The rural credit market in southern Sweden I775-I808: a study of borrowers and lenders. Mimeographed paper for the Fifth European Social Science History Conference, Berlin 24-27 March.

UTTERSTRÖM, G. (I957). Jordbrukets arbetare, vol. I. Stockholm: Tidens förlag. 